

\title{
Development of Collaborative Learning Models in Improving Student Social Skills In Biology Science
}

\author{
Geterudis Kerans ${ }^{1}{ }^{*}$, Khristoforus Palli Ngongo ${ }^{2}$ \\ ${ }^{1}$ Lecturer of Natural Science Education at STKIP Weetebula, Weetebula, Sumba Barat Daya, Indonesia. \\ ${ }^{2}$ Lecturer of Primary School Teacher Education at STKIP Weetebula (STKIP), Weetebula, Sumba Barat Daya, Indonesia.
}

DOI: $\underline{10.29303 / \text { ippipa.v7i3.724 }}$

\section{Article Info}

Received: April 28, 2021

Revised: June $2^{\text {th }}, 2021$

Accepted: June 7th, 2021

\begin{abstract}
This study aims to improve students' social skills through a collaborative learning model in Basic Biology courses. This is a research and development (R\&D) study. This research consists of six stages, namely: (1) a preliminary study which is evaluative and explorative in nature toward the previous learning model, (2) designing a conceptual model, (3) validating the model, (4) testing the conceptual model, (5) ) revising the results of trials model in order to obtain a final model, and (6) composing the research reports. The development of a collaborative learning model can improve students' social skills. The increasing of students' social skills can be seen from the skills of students while working in groups, respecting each other's opinions, helping each other in completing assignments and reminding each other in making notes in each other's books and the distribution of tasks during presentations so that each group member has the opportunity to speak.
\end{abstract}

Keywords: Development; Collaborative Model; Social Ability.

Citation: Kerans, G., \& Ngongo, K. (2021). Development of Collaborative Learning Models in Improving Student Social Skills In Biology Science. Jurnal Penelitian Pendidikan IPA, 7(3), 357-363. doi:https://doi.org/10.29303/jppipa.v7i3.724

\section{Introduction}

National Education aims to develop the potential of students to become human beings who believe and fear God, have a noble character, healthy, knowledgeable, competent, creative, independent, and become democratic and responsible citizens. National Education has function to develop the capabilities and shape the character and dignity of nation in order to educate the nation's life (Constitution of the Republic of Indonesia, 1945). In order to answer these goals and functions, education must be able to educate and train the students to be able to develop themselves and compete with others in society. As a social being, the life of each individual cannot be separated from they interactions with other individuals and the environment in which he/she lives. To be able to interact well, education does not only train the students with cognitive abilities but also with social skills. Social skills define as a person's ability or skills to interact and communicate with others (Parji, 2016).

The current educational process has experienced a paradigm shift where the learning process in the classroom is no longer a process of transferring knowledge from teachers to students but more than that, the teachers are expected to act as facilitators who help and support students by providing facilities and conditions that help students to construct their understanding of the materials which are studied. The teacher must be able to create a discussion space for students so that they are able to communicate what is on their mind. Learning can be perceived successful if the students are actively involved and perform results in accordance with the learning objectives. An active communication and collaboration between students and between students and teachers are very important 
to make a quality learning process. This condition can be created if the appropriate learning model is applied and could become a bridge that helps the good communication run.

Based on the results of observations made in the lecture process, researchers found that there were various problems in the lecture process related to students' social skills. The problems that always arise are 1) the students are not really active in asking or answering lecturer questions; 2) only one or two students who are often active in asking 3) in doing assignments/group discussions, there are always one or two students who help other group members by doing the group task by them and the rest of the students only include their name; 4) during the group assignment presentation, only certain students in the group who are able to explain the results of their discussion, while the others do not even understand what is written in the assignment; 5) students are lack of enthusiasm to dig deeper about what is learned; 6) students do not have complete notes and copies of assignment files that have been collected; 7) student test results show $70 \%$ of students do not achieve their learning objectives. Students' social abilities are very lacking, even in group discussions, many of them are just silent and this is the reason students when forming groups, students want to choose their own group friends.

Based on the description of the problems found, the researchers were interested in conducting development research using a collaborative learning model to be able to improve students' social abilities in the Basic Biology course. The purpose of this study is to improve students' social skills by using collaborative learning model development. Collaborative learning model is learning that places students with diverse backgrounds and abilities to be able to work together in small groups to achieve common goals (Mahmudi, 2006). Through collaborative learning, students are expected to be able to communicate with each other and help each other in doing discussion assignments according to the materials of the course. Collaborative learning also allows the transfer of knowledge from students with different abilities in a small group. Collaborative learning is one of the alternatives that are considered appropriate to improve student social skills. The expected social skills from students they can be formed in group randomly with other students who have different background abilities and they can discuss and remind each other in doing assignments.

Model development is defined as a conceptual design process in effort to increase the function of existing models, through the addition of learning components that are considered to improve the quality of achieving goals (Rusmin, 2012). Model development can be interpreted as an effort of expanding to bring a condition to a more perfect or more complete and better condition. In this study, the development of the model is the addition of another approach in order to create an atmosphere to answer student problems. The development used by adding the application of the point system in groups where personal score could affect the group score. This is done to create conditions of learning and working together, contributing to each other's thoughts and being responsible for the achievement of learning outcomes in groups and individually. The application of the point system has some weaknesses of collaborative learning, which are 1) Sometimes students' responses and opinions often deviate from the learning material or problems; 2) It takes a lot of time; 3 ) There is selfish character among the students, low self-esteem and just hoping other do the assignments; 4) material conclusions are sometimes difficult to reach (Rusmin, 2012).

The application point system as reward and punishment is expected to motivate the students to be more active in the process of improving the social skills which is being assessed. Reward (Award) is one of the basic needs that encourage someone to actualize himself. A person will continue strive to improve and maintain his self-actualization if the implementation of the discipline results achievement and productivity make him/her gets an award. Award is a reward for the good results of students in the educational process. Meanwhile, Punishment is an action that is imposed on the students consciously and deliberately to cause a harsh effect and make the child think not to repeat the mistake. Punishment is given if reprimands and warnings are not able to prevent children from committing violations (Yon, 2018).

\section{Method}

This research is a research development (Research and Development). This research was conducted at STKIP Weetebula. The subjects of the research are students from second semester of Mathematics Study Program in Basic Biology subject. This research was conducted for 6 months starting from July 2019 to December 2019. In Research and Development (R \& D) Borg and Gall (1983) argues that research and development (R\&D) is "a process is used to develop and validate educational products". R\&D is often used as a strategy to improve the quality of education, validate educational outcomes, discover new knowledge, answer questions on practical problems through "applied research". Overall, this research consists of six related stages, namely: (1) a preliminary study which is evaluative and explorative in nature to the previous learning model, (2) designing 
a conceptual model, (3) validating the model, (4) testing the conceptual model, (5) revising trial results to obtain a final model, and (6) compiling research reports. In simple terms, the research steps can be seen in Figure 1.

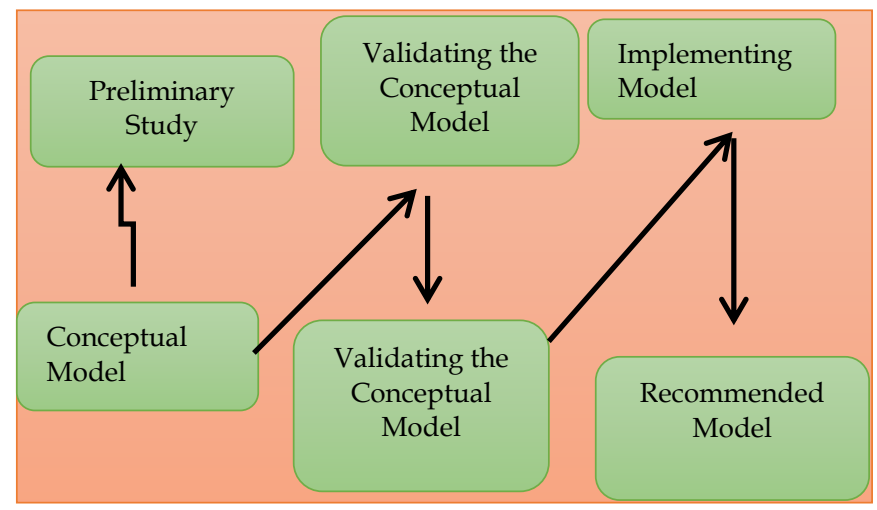

Figure 1: The Steps of Developing Learning Model

The data collection technique used in this research is observation. It aims to see the social skills of students which include the skills to work with others, the skills to convey opinions and ideas, leadership skills, respecting others, the skills to accept other people's opinions and skill to help others and the skill of taking turns or sharing. Observations are done in every meeting using the observation sheet. The observation sheets used were about the student activity in group discussions, observation of presentation, and observation for question-and-answer activities. Besides, there was also a final test in the form of a group interview test to see the level of social skills which was obtained at the end of the lecture process.

\section{Result and Discussion}

\section{Preliminary Study Stage}

Preliminary study us done in previous lectures where the lecture process is carried out using the lecture and group discussion methods. In previous lectures, the lecturer observed that by using the lecturing method, students became passive and when they are given space for questions and answers, only $10 \%$ of students involved in the lecture process and asked questions or answered questions from the lecturer. Students who were active are only certain people and are always the same in every meeting.

In group discussion assignments, the lecturer observed that only $20 \%$ of the students were fully involved in doing the assignments while the others were very passive and dependent on their group friends. During the presentation, only few students who were active during the discussion were able to explain the results of the discussion, while other group friends tend to speak and choose to be silent and did not answer the questions. This sometimes becomes an obstacle because the process takes a long time and, in the end, it is the same student who has to answer. This same problem is found not only in basic Biology classes but in several other lecture classes.

\section{Conceptual Model}

Based on the results of the preliminary study, the researcher developed a learning model that can improve student skills. The model which was developed is a collaborative learning model. Joyce \& Marsha (2000) suggest that a learning model is a plan or pattern that can be used to design face-to-face learning in the classroom to help students achieve various goals. Meanwhile, model development is a conceptual design process in an effort to increase the function of preexisting models, through the addition of learning components which are considered to improve the quality of achieving goals (Rusmin, 2012). In this study, the development of collaborative model used was the addition of a point system in each stage of the collaborative learning model to increase student enthusiasm in developing student social skills. The addition of this point system is based on the results of observations in the previous lecture process, when conventional models and group discussions are used, the students tend to be bored and uninterested to the assignment given and only a few students were involved.

The implementation of the point system takes advantage of the strengthening in the form of rewards which are points and punishment in the form of reducing points that applied to one group. The reinforcement is the giving of rewards to the groups who complete tasks on time, all group members have a record of group work, each member appointed can present or answer questions appropriately in the form of full additional points or points of value 2 . Whereas punishment is given to groups who do not do the good work is a reduction point (-2 points). This group assessment is part of the assessment of students' final grades. Therefore, the points of this group will affect the final score. Purnama (2017) conducted a research on the application of previous points with the results after the application of behavior therapy with reward and punishment techniques, the result was students who had low discipline began to change slowly.

The application of the point system is expected to be a motivation for students to be able to develop social skills and there is hope that the application of the point system will help the final value (Masruroh, 2018). Cleopatra (2015) defines motivation as part of a situation that causes a person to act in a clear way to fulfill certain goals. Obviously, the student's goal is to get a good final score, so that the application of the 
point system in the lecture process can help students to add points that affect their final score.

\section{Learning Model Validation}

The model that has been planned is discussed with other lecturers and gets some valuable inputs, such as, in the application of developing this collaborative model, the lecturer must act more decisively so that students can be motivated. Researchers also received input on how the instruments that can be used in the assessment and what social skills are needed by students who are candidates of teachers.

\section{Composing Observation Instruments}

The research instrument prepared by the researcher was adjusted to the purpose of this study. There are four observation sheets namely the student activity observation sheet in group discussions, the group presentation observation sheet, the questionand-answer activity observation sheet and the student final test interview observation sheet.

\section{Model Implementation}

The implementation of the development of collaborative learning model is done for second semester students of the Mathematics Education Study Program in the Basic Biology course. The number of the students in one class is 40 students.in the first meeting, the lecturer explained the lecture process which will be run for one semester. All the learning and teaching process used a collaborative model with the additional application of the point system. The application of model development carried out in this study are:

1. The lecturer explains the plans for one semester.

2. Students are divided into small groups consist of 45 people randomly by considering the gender and students' abilities

3. This group is valid for one semester of Basic Biology lectures

4. Each group will get an assignment and for each assignment, group members will take turns to become the task leader. During this lecture there were five assignments given so that all members experiences each of them is group leader.

5. In the assignment, the group leader was responsible to coordinate his/her friends to work on group assignments and the task will be communicated to the lecturer. After receiving the revision, the group will revise their work.

6. In the next meeting, the groups must present their group assignments in turn based on teacher's calling randomly. Therefore, the members who were not involved will be noticed. During the presentation, the lecturer observes the student's presentation skills.
7. After doing presentation, the group will open an opportunity for other groups to ask questions or suggestions and then group members will respond to friends' questions in turn. Those who answer are the members appointed by the lecturer.

8. After all groups had their presentation, the lecturer will respond and invite students to reflect on the benefits of the material studied in daily life.

9. The point system applied to each assignment process. Assignments that are collected on time and written neatly in the notes of each group member will make the group get an additional 2 points, but if there are still members who have not written the results of the discussion in their answers, all group members will get minus 2 points.

10. Apart from the discussion process and writing assignments, during the presentation for groups where all members can present the results of the discussion well, they will get additional 2 points.

Student social skills observed in Biology Science include: (1) Skills to work with others; (2) Skills to convey opinions and ideas; (3) Skills of leadership; (4) Skills to respect others; (5) Skills to accept other people's opinions; (6) Skills to help others, and (7) Skills shifting or sharing.

The result of process implementing collaborative learning model development in basic biology lectures in the first assignment, students' social skills were not too prominent. During the discussion there were still students who were silent and not involved in the discussion. During the presentation there were still one or two students in the dominant group and when asked to take turns explaining there were still students who were unable to speak and were only silent and in the end were helped by other members. By looking at their notes, the results of the discussions that were examined, there were still one or two students who had not completed their notes but the assessment was still carried out by the lecturer in accordance with the conditions agreed at the first meeting.

The application of the point system helped students to be actively involved in lectures and this begins to appear in 2 to 5 assignments. During the discussion, the students appeared to be active, each member accepted the tasks given by the head of the group assignment at that time with enthusiasm and completed it on time. The head of the group assignment also began to show his confidence but still respected his friend's opinion. During the consultation it could be seen that each member had completed their part well and during the presentation the ability of each group member to communicate was improved. When the students are appointed by the lecturer to explain the part being presented, each group member were ready and when they were asked questions, the group 
members were seen having a discussion and then answering their friends' questions.

Collaboration skills could be seen from the results of good group work and based on the learning objectives. The skills to convey opinions and ideas began to improve and was seen during discussions and presentations. Many students asked questions for the presentation group and the presentation group was able to answer these questions by discussing with their friends first. When there was an answer that was not complete or right, other group members helped their friends by asking permission first. This indicates that their mutual respect skill increased. If there are questions that were not answered perfectly, the students raised their hands and then returned to ask questions when given the opportunity. Leadership skills can be obtained because in each task there was a task leader and the all of the student got turn to become a leader.

The result could be seen from the final test which was conducted using the interview method. The test is conducted by interviewing the students in groups. The lecturer asked several questions related to their students' understanding the material from the first to the last meeting. The results were very satisfying where each member of the groups could answer the questions well and gave explanation. Based on all the notes that they have, almost all group members had complete notes which made it easier for them to understand the materials well. In the final results of observation during the test, only two students did not have complete records and this slightly affected their ability to explain the questions given. In the interview test, the skills of mutual assistance and group collaboration also appear, when someone is confused with the questions given, there are other group members who tried to help their friends so that they could answer the lecturers' questions.

Student activeness in learning activities can be seen on how they construct their own knowledge. They actively build an understanding of the problems or everything they face in the learning process (Vascolino \& Febiola. 2020).

The increase in social skills that occurs in the application of this collaborative learning model is in line with what was said by Barkley, et al. (2012) which perceives that collaborating is doing something with another person. In collaborative learning students learn in pairs or form small groups to achieve goals. In collaborative learning, each group member can learn from each other, even lecturers can learn from their students. If the lecturer assigns students in groups to study different topics, the lecturer will be able to learn a lot from them (Marmah, 2014). There are five elements that must be fulfilled in collaborative learning, including: a) interdependence; b) individual responsibility; c) face-to-face interaction; d) application of collaborative skills; e) group process. Collaborative learning becomes important in improving social skills because each collaborative learning step is packaged. Therefore, there is a positive interaction between collaborating individuals.

Panitz (1996) in his article explains that collaborative learning is a personal philosophy, not just a classroom learning technique. Collaboration is a philosophy of interaction and a lifestyle that makes collaboration as an interaction structure designed in such a way as to facilitate collective efforts to achieve common goals. In all situations, when a number of people are in a group, collaboration is a way to relate mutual respect and respect the abilities and contributions of each group member. In this process, there is a division of authority and acceptance of responsibility for each member of the group involved. Collaborative learning grows cooperation between group friends, mutual respect for opinions, honesty and the habit of helping each other between group members. Collaborative learning activities teach the students good habits to understand what is being learned, the attitude of wanting to do something and the skills to do something.

Fermiska \& Hutauruk, (2020) argues that there are five basic elements of cooperative/collaborative learning in a group, which are: positive interdependence: in each learning process each student must feel positively dependent and have a bond between fellow group members with the responsibility of: (1) mastering the learning material; and (2) ensure that all members of the group master it. Someone feels they will not be successful if other students are not successful either. Direct interaction between students: the best collaboration results can be obtained by the existence of verbal communication between students which is supported by positive mutual dependence. Students must face each other and help each other in achieving learning goals. Individual responsibility: in a working group, students must be able to contribute, support and help one another. Each student is required to master the material used as the subject matter. Each member of the group is responsible for learning the subject matter and is also responsible for group learning outcomes. Collaboration skills: students' social skills are very important in learning. Students are required to have collaborative skills, so that in groups there is a lot of interaction dynamic to learn from each other and teach as part of the collaborative learning process. Group process effectiveness: students process the effectiveness of their study groups by explaining which actions contribute to learn and which are not and 
making action decisions that can be continued or that need to be changed.

Social skills are the ability of individuals to communicate effectively with others both verbally and nonverbally based on the situations and conditions that exist at that time, these skills are learned behaviors. This social ability increases in this collaborative process because of the existence of a point application system which motivates the students to be actively involved and improve their abilities so as not to get minus points and not to harm their friends. In addition, there is help from another friend who always reminds him that one person's mistake will become a point for one group. This is in line with the opinion of Libet and Lewinsohn who argued that social skills as a complex ability to show good behavior which are assessed positively or negatively by the environment, and if the behavior is not good, it will be given punishment by the environment. Social skills, either directly or indirectly, help adolescents to be able to adjust to the standards of society's expectations in the norms that apply around them (Vascolino \& Febiyola, 2020).

Based on the results of research conducted by researchers in improving students' social skills by developing collaborative learning models, there are several advantages over other methods, including: (1) Students can carry out social interaction and communication in their groups; (2) Students can work together well in completing their assignments; (3) Student are active in the classroom by involving themselves in asking asking, answering and responding to their friends and lecturers; (4) Students have the habbit of helping each other to understand the concept of the material being studied; (5) Maintaining the communicative relationships and cooperation in groups; (6) Through group activities, students can have positive personal relationships; (7) Students share tasks, such as in doing the assignments, presentations and answering questions from other groups; and (8) Students are trained to be leaders by being assigned as group leaders in turn.

However, the development of collaborative learning still has weaknesses or obstacles in its application, including: (1) Relatively requires long time; (2) Very dependent on consistency and assertiveness of the teacher in its application; (3) Student activities and student awareness are needed; (4) Requires the use of good learning resources by students; (5) Building student character is a long process and requires persistence and patience.

\section{Conclusion}

The development of collaborative learning models can improve students' social skills. The development used is the implementation of collaborative learning added with the point system approach to increase student enthusiasm and enthusiasm in developing the social skills being assessed. The social abilities of students observed in this study included the skills to work with others, the skills to convey opinions, ideas and ideas, leadership skills, respect for others, the skills to accept other people's opinions, the skills to help others and the skills to take turns or share.

\section{Acknowledgements}

Researchers say many thanks to All leaders of STKIP Weetebula for all their assistance in this research, Mathematics Education Study Program lecturers who have provided the opportunity for researchers to conduct trials in their Study Program, STKIP Weetebula Lecturers for their input and suggestions, Students of Mathematics Education Study Program who have been involved in this research.and for my beloved husband, children's and family.

\section{References}

Barkley, Elizabert E., Cross, K. Patricia \& Major, Clair Howell. (2012). Collaborative Learning Techniques: Teknik-teknik Pembelajaran Kolaboratif. Penerjemah: Narulita Yusron. Bandung: Penerbit Nusa Media.

Borg,W.R and Gall,M.D. (1983). Education Research: An Introduction. New York: Longman.

Cleopatra, M. (2015). Pengaruh Gaya Hidup dan Motivasi Belajar Terhadap Prestasi Belajar Matematika, Jurnal Formatif, 5 (2), 168-181. doi: http://dx.doi.org/10.30998/formatif.v5i2.336 [Indonesian]

Fermiska, S,T., \& Hutauruk, A. F. (2020). The Application of Cooperative Learning Model during Online Learning in the Pandemic Period. Budapest International Research and Critics Institute-Journal (BIRCI-Journal), 3(3), 1683-1691. doi:https:// doi.org/10.33258/birci.v3i3.1100

Gani, Y. (2018). Penerapan Reward and Punishment melalui Tata Tertib Sistem Point dalam Meningkatkan Kualitas Pendidikan Karakter. Jurnal Ilmiah AL-Jauhari: Jurnal Studi Islam Dan Interdisipliner, 3(1), 33-48. doi: https://doi.org/10.30603/jiaj.v3i1.685.

[Indonesian]

Joyce, B. \& Marsha, W. (2000). Models of Teaching. London: Allyn \& Bacon.

Mahmudi, A. (2006). Pembelajaran Kolaboratif. Seminar Nasional MIPA: Yogyakarta. [Indonesian] 
Marmah, A. A. (2014). Students' Perception About the Lecture As a Method of Teaching in Tertiary Institutions. Views of Students From College of Technology Eduction, Kumasi (Coltek). International Journal of Education and Research, 2(6).

Masruroh. (2018). Penerapan Sistem Point Kehadiran untuk Menanamkan Karakter Disiplin pada Mata Kuliah Manajemen Sains. Jurnal Penelitian Pendidikan IPA, 3 (2). $\underline{h}$ doi: http://dx.doi.org/10.26740/jppipa.v3n2.p45-49. [Indonesian]

Panitz, T. (1996). Deliberations Collaborative Learning. Retrieved from: http://www.londonmet.ac.uk/deliberations/col laborative-learning/panitz-paper.cfm

Parji, \& Reni, E. A. (2016). Upaya Peningkatan Keterampilan Sosial Siswa Melalui Permainan Tradisional Congklak. Gulawentah: Jurnal Studi Sosial, 1(1), 14-23. doi: http://doi.org/10.25273/gulawentah.v1i1.27. [Indonesian]

Purnama, R. (2017). Terapi Behavior dengan Teknik reward dan Punishment dalam Meningkatkan Disiplin Diri Anak Usia Pra Sekolah Kelas TK A RA Darul Hafidhin Wonocolo Surabaya, Skripsi S1, Universitas Islam Negeri Surabaya. Retrieved from:

http://digilib.uinsby.ac.id/19173/1/Abstrak.pd f. [Indonesian]

Rusmin, H. (2012). Pengembangan Model Pembelajaran Kolaboratif dalam Meningkatkan Hasil Belajar Warga Belajar Paket C. Disertasi. Universitas Pendidikan Indonesia: Bandung. [Indonesian]

Vascolino, P., \& Febiyola W. (2020). Implementasi Model Collaborative Learning: Sebagai Landasan untuk Membangun Keterampilan Sosial dan Keaktifan Mahasiswa. Jurnal Maneksi 9 (1). doi: https://doi.org/10.31959/jm.v9i1.325. 